\title{
DEFINING DROUGHT IN A TEMPERATE RAINFOREST
}

\author{
Deborah J. Bathke, Holly R. Prendeville, Aaron Jacobs, Richard Heim, Rick Thoman, and Brian Fuchs
}

D rought is a natural part of climate and occurs in nearly all areas of the world. Generally speaking, drought results from a lack of precipitation or changes in the timing, frequency, or type of precipitation. Drought is considered relative, compared to a historical balance between water availability and use. Regionally specific differences in precipitation, landscape features, ecological characteristics, and societal characteristics affect the area's drought exposure, sensitivity, and resulting impacts (Crausbay et al. 2017). Because drought is defined according to these regional differences, it lacks a universal definition (Wilhite et al. 2007).

Despite these qualifiers, the word drought often brings to mind searing heat; dry, cracked Earth; empty riverbeds; emaciated animals; and scorched vegetation. Drought manifests differently in the temperate rain forest of southeast Alaska (SEAK), where mean annual temperatures range from about $3^{\circ}$ to $8^{\circ} \mathrm{C}$ and, on average, annual precipitation ranges

AFFILIATIONS: BATHKE AND FUCHS-National Drought Mitigation, University of Nebraska-Lincoln, Lincoln, Nebraska; PrendeVILle-Northwest Climate Hub, USDA, Portland, Oregon; JACOBS—Juneau Weather Forecast Office, NWS, Juneau, Alaska; HEIM-NOAA/National Centers for Environmental Information, Asheville, North Carolina; Thoman-Alaska Center for Climate Assessment and Policy, Fairbanks, Alaska

CORRESPONDING AUTHOR: Deborah J. Bathke,

dbathke2@unl.edu

DOI:10.1175/BAMS-D-19-0223.I

In final form 16 July 2019

(C)2019 American Meteorological Society

For information regarding reuse of this content and general copyright

information, consult the AMS Copyright Policy.

\section{SOUTHEAST ALASKA DROUGHT WORKSHOP: LESS RAIN, WARMER TEMPERATURES, AND TRANSITIONING FROM A SNOW TO RAIN SYSTEM}

WHAT: More than 80 participants, representing local government, Alaska Native communities, state and federal agencies, nongovernmental organizations, academia, businesses, utilities, and the media, met in person and remotely to gather information about drought impacts in southeast Alaska and improve understanding of what constitutes a drought in a temperate rain forest.

WHEN: 7 May 2019

Where Juneau, Alaska

from 981 to more than $6,000 \mathrm{~mm}$ (Alaska Climate Research Center 2019). With June 2018 to May 2019 precipitation averaging about $74 \%$ of the long-term average, parts of the Panhandle are experiencing the consequences of drought despite receiving upward of $2,000 \mathrm{~mm}$ of rain (NOAA 2019). These deficits were the largest for this 12-month period in the region's period of record (1925-present) and contributed to the state's first extreme drought classification by the U.S. Drought Monitor (USDM) in the map's 20-yr history [National Drought Mitigation Center (NDMC); NDMC et al. 2019].

The relative infrequency of drought in the region presents challenges for those tasked with monitoring drought conditions (Associated Press 2018). While numerous drought indices have been developed (Svoboda and Fuchs 2016), many of these are either ill suited for climates outside of the contiguous United States or unavailable because of a lack of continuous data, insufficient record length, or data integrity issues. 
Building upon the success of ongoing efforts between the NDMC and the U.S. Department of Agriculture Climate Hubs to increase awareness of and participation in the USDM process, the two groups partnered to convene a workshop focused on promoting collaboration in drought monitoring, gathering information about the impacts of drought, and developing regional metrics for the USDM.

WORKSHOP FORMAT. The workshop's format aimed to promote mutual learning (Schusler et al. 2003) by increasing participant knowledge about drought monitoring and management efforts while at the same time gathering diverse drought perspectives and experiences to create regionally relevant information that could be used to enhance those same efforts. Strategies for fostering mutual learning included

- incorporating domain and traditional knowledge from a variety of fields (e.g., ecology, agriculture, climatology, hydrology, policy, utilities, community development, and the media);

- allowing time for small group discussions related to the effects of drought and their interconnectedness to other aspects of human and natural systems;

- including a variety of viewpoints through diversity in demographics, cultural backgrounds, and interests (e.g., federal, state, and local agencies, Native communities, academia, and the private sector); and

- extending engagement beyond the meeting with continued feedback on developing regional drought metrics.

FINDINGS. Drought awareness and education. A clear need for increased public awareness and education emerged from the workshop. For example, when asked to identify their first thought upon hearing that parts of SEAK were in a drought, some participants responded with disbelief, using words such as "really?" and "surprising." One of the most memorable quotes came from a participant who said, "Until [someone] from the National Weather Service called our office and informed us that we were in a class D2 drought, we were unaware that the conditions that we were experiencing had that official definition. That made us take a fresh look ... at what we were experiencing." Participants also noted issues related to people's perception of whether drought is occurring. For example, well-managed systems may initially mask the effects of drought, "making it hard to say that drought is happening." Additionally, they stated that "baselines are changing and the perspective of normal varies by generation." Given that the current drought in SEAK is the most significant drought in the wet season in decades, many current residents have not experienced drought conditions of the duration and severity seen by previous generations. This lack of exposure to drought, as some pointed out, may mean that more holistic approaches for mitigation and adaptation are needed that include other extreme events, population growth, and climate change. To address the need for increased awareness and education, participants recommended opportunities related to tribal outreach activities and the retreat of nearby Mendenhall Glacier.

Collaboration and coordination in drought monitoring. Drought monitoring involves the continuous assessment of natural indicators of drought severity, spatial extent, and impacts. While a variety of data and tools exist for assessing conditions, the USDM is arguably one of the most recognized drought monitoring products with over 10 million page views per year (NDMC 2019). Produced jointly by the USDA, NOAA, and the NDMC, the USDM is unique in that it blends quantitative indices and indicators with qualitative "on the ground" reports from a network of over 400 local experts. While the USDM has been adopted by many sectors and is a key indicator for federal and state policy decisions, including the distribution of hundreds of millions of dollars of agricultural financial relief, many people are unfamiliar with the map's creation process. A poll administered at the workshop revealed that the majority of the participants (56\%) were not aware of the USDM process (i.e., that they could report drought impacts or give feedback or input to draft maps). Only $6 \%$ considered themselves well versed on the map's creation process. Notably, one participant stated, "While I use the USDM in my job, I never considered contributing to it." With only three participants on the USDM listserv, and despite having the largest land area of any state, Alaska is among those states with the lowest number of contributors. This limited participation, combined with the state's sparse data networks and unique climate, hampers the making of the USDM and has an effect on the map's accuracy. Additionally, the lack of input from the state raised concern that "information on drought impacts is not being elevated in Alaska, therefore funding triggered by the USDM is not making its way into many Alaskan communities." Increasing local information into the map is critical. Potential ways identified by workshop participants included community-level 
impact collection through existing tools such as CoCoRaHS (https://cocorahs.org) and the Drought Impact Reporter (https://droughtreporter.unl .edu), incentivizing crowdsourced data collection, and organizing regular webinars to discuss current climate issues.

Besides the need for more human involvement, discussions revealed a need for additional and improved monitoring data to better capture the spatial variability and intensity of precipitation, soil moisture, streamflow, lake levels, and the loss of water from ice fields. Suggestions include partnering with cell phone companies to add instrumentation and leveraging existing data networks in the region.

Drought impacts in SEAK. A drought impact is defined as an observable loss or change that occurs because of drought. Understanding the full range of impacts is critical for monitoring and managing drought. Impacts provide context for drought indices, offer insight into on-the-ground severity, and are important for characterizing societal vulnerability and targeting mitigation and response activities (Wilhite et al. 2007). While efforts to collect drought impact information exist, relatively few impacts have been reported in Alaska (NDMC 2019). To help fill this data gap, participants shared their unique perspectives on what drought looks like in SEAK (Table 1). Participants noted the lack of representation and detailed discussion for tourism, infrastructure, and differing socioeconomic groups.

Revising drought metrics. Following the workshop, workshop organizers (which included two USDM authors and two local experts on the USDM listserv) discussed integrating workshop outcomes into metrics for the USDM. This included identifying the relevant indicators and indices, appropriate monitoring time scales, and linking impacts to the drought intensity categories used in the USDM. Preliminary recommendations include the following:

- incorporating either the self-calibrated or Canadian modified Palmer drought severity index, which would account for local soil and climate characteristics;

- focusing on time scales of three months or less to identify areas going into drought and time scales of six-plus months for those currently in drought;

- coordinating with the Canadian Drought Monitor; and

\begin{tabular}{|c|c|}
\hline Sector & Drought impacts \\
\hline \multirow[t]{3}{*}{ Wildlife } & Reduced availability or quality of food \\
\hline & Increased mortality \\
\hline & Increased interactions with people \\
\hline \multirow[t]{3}{*}{ Forests } & Increased pressure from pests \\
\hline & Defoliation \\
\hline & Drying and/or burning of duff and salal \\
\hline \multirow[t]{4}{*}{ Fisheries } & Harmful algae blooms \\
\hline & Increased mortality \\
\hline & Prevention or reduced efficacy of spawning \\
\hline & Shift in timing of salmon runs \\
\hline Subsistence way of life & Reduced availability or suitability of subsistence foods, crops, and materials \\
\hline \multirow[t]{3}{*}{ Water supply } & Reduced availability for municipal uses \\
\hline & Reduced hydropower production \\
\hline & Implementation of water restrictions \\
\hline \multirow[t]{3}{*}{ Tourism and recreation } & Limited operations for ski areas \\
\hline & Increased costs for snow making \\
\hline & Reduced opportunities for rafting \\
\hline \multirow[t]{2}{*}{ Communities } & Increased costs for power \\
\hline & Reduced air quality due to supplemental diesel generation \\
\hline
\end{tabular}


- replacing the current list of potential impacts on the USDM drought classification table (NDMC et al. 2019) with regionally relevant impacts (Table 1).

LOOKING AHEAD. Continuing progress on understanding drought and revising drought monitoring metrics in SEAK is no small undertaking. Recent research developed a methodology to link multisector impacts to drought severity levels to develop statespecific impact tables for the USDM (Noel 2019) based on impacts captured in the Drought Impact Reporter. Given the lack of impacts from Alaska, consideration needs to be given to incorporating the findings from this workshop. This process likely includes relating the historical occurrence of impacts with measurable data, vetting findings with local scientific experts, and seeking input and approval from the USDM authors and steering committee. Recognizing that other parts of Alaska will have their own unique drought impacts and challenges, participants recommended holding similar workshops in the interior and south-central parts of the state.

ACKNOWLEDGMENTS. This workshop was coorganized by the USDA Northwest Climate Hub, NDMC, NWS Juneau Weather Forecast Office, Alaska Climate Adaptation Science Center, and NOAA National Centers for Environmental Information. Financial support was provided by the USDA Office of the Chief Economist, Cooperative Agreement 58-0111-18-018.

\section{REFERENCES}

Alaska Climate Research Center, 2019: Alaska climate normals. Alaska Climate Research Center, accessed 30 May 2019, http://akclimate.org/Climate /Normals.

Associated Press, 2018: Parts of southeast Alaska experience drought conditions. Seattle Times, 13 June 2018, www.seattletimes.com/nation-world /apxparts-of-southeast-alaska-experience-drought -conditions/.

Crausbay, S. D., and Coauthors, 2017: Defining ecological drought for the twenty-first century. Bull. Amer. Meteor. Soc., 98, 2543-2550, https://doi.org/10.1175 /BAMS-D-16-0292.1.

NDMC, 2019: National Drought Mitigation Center. Accessed 30 May 2019, http://drought.unl.edu.

— , USDA, and NOAA, 2019: United States Drought Monitor. Accessed 24 June 2019, https:// droughtmonitor.unl.edu/AboutUSDM.aspx.

NOAA, 2019: Climate at a glance. National Centers for Environmental Information, accessed 27 June 2019, www.ncdc.noaa.gov/cag/global/time-series.

Noel, M., 2019: Developing a framework to link multisector drought impacts to drought severity at the state level. M.S. thesis, School of Natural Resources Sciences, University of Nebraska-Lincoln, 123 pp.

Schusler, T. M., D. J. Decker, and M. J. Pfeffer, 2003: Social learning for collaborative natural resource management. Soc. Nat. Resour., 16, 309-326, https:// doi.org/10.1080/08941920390178874.

Svoboda, M., and B. Fuchs, 2016: Handbook of drought indicators and indices. World Meteorological Organization and Global Water Partnership Rep., $52 \mathrm{pp}$.

Wilhite, D. A., M. D. Svoboda, and M. J. Hayes, 2007: Understanding the complex impacts of drought. Water Resour. Manage., 21, 763-774, https://doi .org/10.1007/s11269-006-9076-5. 